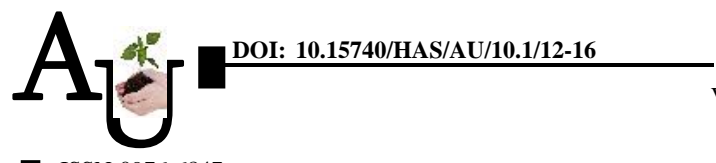

- ISSN-0976-6847

\title{
Research Aвticle: Personal profile of bhil (tribal) farmers for their livelihood status of Nandurbar district in Maharashtra state
}

Article Chronicle :

Received :

24.03.2012;

Revised :

20.12.2014;

Accepted :

06.01 .2015

Key Words :

Livelihood status, Ex

post facto research

Author for correspondence :

PRAKASH L. PATEL

Department of Extension

Education, K.V. Patel

College of Agriculture,

Shahada, NANDURBAR

(M.S.) INDIA

Email: saac555@gmail.

com

See end of the article for

authors' affiliations

SUMMARY : The present study was conducted in Khandesh region of Maharashtra state on studies on livelihood status of bhil farmers of Nandurbar district in Maharashtra. Total 20 villages from four selected talukas were identified for the present study. Ex post facto research design was used and 200 sample size were selected for the study by using random sampling method. The data were collected by personal interview method. Twelve independent and one dependent variables were taken for the study. The collected data were analyzed by using appropriate method of analysis viz., multiple regression analysis and step down regression analysis. Percentage, mean, rank, standard deviation and correlation co-efficient.

How to cite this article : Patel, Prakash L., Salunkhe, Sumit R. and Koli, Mukesh A. (2015). Personal profile of bhil (tribal) farmers for their livelihood status of Nandurbar district in Maharashtra state. Agric. Update, 10(1): 12-16. 